\title{
Cell Culture and Gene Expression Studies in Relation to Biomineralization in the Black-lip Pearl Oyster, Pinctada margaritifera
}

Vasudevan Srinivasa Raghavan ${ }^{\dagger *}$, Vidya Jayasankar ${ }^{\dagger}$, Cheruvathoor Poulose Suja ${ }^{\dagger}$, and Pappurajam Laxmilatha ${ }^{\dagger}$

${ }^{\dagger}$ Madras Research Centre of ICAR-

Central Marine Fisheries Research Institute Chennai, Tamil Nadu, India

Tuticorin Research Centre of ICAR-

Central Marine Fisheries Research Institute

Tuticorin, Tamil Nadu India

\section{ABSTRACT}

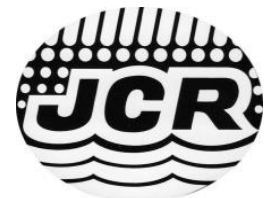

www.JCRonline.org

Srinivasa Raghavan, V.; Jayasankar, V.; Suja, C.P., and Laxmilatha, P., 2019. Cell culture and gene expression studies in relation to biomineralization in the black-lip pearl oyster, Pinctada margaritifera. In: Jithendran, K.P.; Saraswathy, R.; Balasubramanian, C.P.; Kumaraguru Vasagam, K.P.; Jayasankar, V.; Raghavan, R.; Alavandi, S.V., and Vijayan, K.K. (eds.), BRAQCON 2019: World Brackishwater Aquaculture Conference. Journal of Coastal Research, Special Issue No. 86, pp. 156-163. Coconut Creek (Florida), ISSN 0749-0208.

\begin{abstract}
Nacre is composed of aragonite platelets and organic material formed by molluscs as inner shell layer through biomineralization process, and mantle epithelial cells control nacre formation. A primary culture of granulated epithelial cells was established from mantle tissue of Pinctada margaritifera, through a process of continuous subculturing at $28^{\circ} \mathrm{C}$ in yeast supplemented sea water culture medium. Nuclear beads were placed in culture wells containing semi-solid agar medium and incubated in vitro with cultured granulated epithelial cells in order to evaluate the nacre secretion. On visual observation, a brown coloration was observed on the surface of the bead after 7-10 days. Evaluation of the surface of the nuclear beads by scanning electron microscopy (SEM) after 60 days of incubation revealed a good brick and mortar pattern, characteristic of nacreous layer formation. A lustrous hue was also seen to develop on bead surfaces after this stage. SEM images of a cross section of the nacre-coated bead showed a pattern of arrangement of aragonite tablets similar to that seen in cross sections of the nacre layer of shell of molluscs. The functional ability of cultured granulated epithelial cells was further confirmed by detecting gene expression of two matrix proteins, nacrein and amorphous calcium carbonate binding proteins (ACCBP), which play an important role in formation of the nacreous layer, in both cultured cells and in native mantle tissue. Amplification products for nacrein $(480 \mathrm{bp})$ and ACCBP $(500 \mathrm{bp})$ genes were obtained in both native mantle tissue and in vitro cultured mantle epithelial cells. There was good correlation between the expression patterns of the two genes in in vitro cultured cells and in native mantle tissue, signifying that cultured mantle epithelial cells retain their functional characteristics of biomineralization.
\end{abstract}

ADDITIONAL INDEX WORDS: ACCBP, biomineralization, mantle, nacre, nacrein, pearl oyster.

\section{INTRODUCTION}

Natural saltwater pearls are formed as a defense mechanism when an irritant such as a parasite or sand particle enters between the two shells of a pearl-producing mollusc. The mantle layer secretes a nacreous material which covers the irritant in several layers ultimately resulting in the formation of a lustrous pearl. Cultured pearls are produced similarly through a process wherein the foreign object (nucleus) is introduced artificially between the mantle and the shell. The structure of the inner layer of the shell in molluscs is identical to that of pearls and is composed of nacre or mother-of-pearl. Nacre is a composite material consisting of calcium carbonate $\left(\mathrm{CaCO}_{3}\right)$ in the form of aragonite tablets and an organic matrix. The organic matrix is a mixture of proteins, glycoproteins, chitin, polysaccharides and lipids which controls formation of the $\mathrm{CaCO}_{3}$ polymorphs and the crystal shape (Weiss et al., 2000). The aragonite tablets are arranged in layers separated by the inter-lamellar matrix.

DOI: 10.2112/ SI86-024.1 received 28 March 2019; accepted in revision 14 May 2019.

*Corresponding author: vetvsr@gmail.com

${ }^{\circ}$ Coastal Education and Research Foundation, Inc. 2019
Two models of nacreous arrangements are found in molluscs depending on the stacking mode of the tablets: the sheet nacre model of bivalves, described as the "brick and mortar" arrangement, where in the bricks correspond to the aragonite tablets and the mortar represents the soft organic matrix that bonds the aragonite tablets; and the columnar nacre model which is characteristic of the gastropods (Hedegaard, 1997). Pearls can generally be classified into three types based on their crystal structures on the surface; nacreous pearls and prismatic pearls, covered with nacreous and prismatic layers, respectively, and organic pearls covered with dark brown secretions with or without calcium carbonate crystals (Wada, 1962). Pearls are attractive because they exhibit iridescent colour, which is caused due to diffraction, diffraction and interference, or interference alone by the layers of the nacre.The orderly organization of the crystals and organic matrix produces luster by reflecting light uniformly from the layered compartment (Liu et al., 1999).

Mantle epithelium plays a central role in shell and pearl formation. The mantle edge is responsible for the formation of the prismatic layer, whereas the mantle pallium contributes to the formation of the nacreous layer. During pearl formation the outer mantle epithelial cells proliferate and form a pearl sac 
surrounding the nucleus; the pearl sac epithelia then begin to secrete calcium carbonate and shell matrix proteins resulting in pearl formation (Awaji and Machii, 2011). Although matrix proteins in the shell account for only $5 \%$ of the mineralized layer, they control nacre formation by regulating the stability and polymorphism of $\mathrm{CaCO}_{3}$ at the molecular level. Several soluble matrix proteins including nacrein, MSI31, MSI60, the N16 family, pearlin, and MSI7 have been isolated from the pearl oyster Pinctada fucata (Xiang et al., 2013). However, the biochemical and molecular mechanisms of the biomineralization pathway are yet to be fully understood. Pearl production under natural and cultured conditions is affected by various environmental factors such as ocean acidification, seawater $\mathrm{pH}$, salinity and water temperature. Therefore, development of an in vitro culture system of viable mantle cells forms an attractive alternative for producing pearls under controlled conditions. Trials for in-vitro pearl production through tissue culture methods have been employed for the last two decades from different pearl producing molluscs (Dharmaraj and Suja, 1998, 2001, 2002, 2004, 2006; Jayasankar et al., 2018; Suja, 2003, 2009; Suja and Dharmaraj, 2005, 2019). However, keeping mantle epithelial cells in a continuously proliferating condition, and ensuring that they retain their shell formation functions for a long period of time are issues that need to be resolved before this application can become fully successful.

The objective of this study was to determine the biomineralization potential of in vitro cultured mantle epithelial cells from the black-lip pearl oyster $P$. margaritifera, and to develop methods to improve nacre formation on bead nuclei in primary cell cultures. To this end, oyster mantle epithelial cells were tested with a different substrate for improvement of cell attachment and nacre coating on bead nuclei.

\section{METHODS}

This section gives details of the experimental animals used for the study, composition of the cell culture medium and cell culture procedures. Experimental protocols followed and analytical methods used during the study are also explained.

\section{Experimental Animals and Tissue Dissection}

Black-lip pearl oysters, $P$. margaritifera were collected from Andaman Islands, India, scrubbed and rinsed thoroughly in tap water and maintained in tanks containing aerated seawater at $32 \mathrm{ppt}$ and $28^{\circ} \mathrm{C}$. Oysters were kept in the tank for at least 1 week without being fed, in order to reduce microbial contaminants. After brushing the shells, the animals were rinsed with $75 \%$ ethanol. The valves of the oysters were then opened carefully and the mantle tissue was dissected and transferred to sterile seawater (SSW). Pallial region of the tissue was trimmed and treated with $35 \%$ alcohol, followed by 2 baths of 5 min each of antibiotic/antimycotic solution in SSW (penicillin 10,000 units/ml, streptomycin 10,000 $\mu \mathrm{g} / \mathrm{ml}$; Gibco, Life Technologies, UK; amphotericin B; Sigma-Aldrich, St. Louis, USA).

\section{Culture of Explants}

The decontaminated mantle tissues were given a final rinse in SSW and minced into 2-3 $\mathrm{mm}^{2}$ pieces. The culture procedure was performed as previously described by Jayasankar et al. (2018). Briefly, tissue explants were transferred to 12-well culture plates and left undisturbed for $\sim 10$ min until the explants adhered to the bottom of the wells, following which $2 \mathrm{ml}$ of SSW medium containing $0.1 \%$ kanamycin antibiotic solution (Sigma-Aldrich, St. Louis, USA), with $75 \mu 1 / \mathrm{ml}$ of $0.1 \%$ yeast extract (Sigma-Aldrich, St. Louis, USA) as supplement was added to each well. Culture plates were maintained at $28^{\circ} \mathrm{C}$ and examined using an inverted microscope (Nikon Eclipse TS100FLED, Japan), to monitorcell proliferation, cell morphology and survival.

\section{Development of Primary Cultures}

Mantle explants were incubated for about 7 days and then the suspension was removed; the cells that had migrated out of the explants and adhering to the bottom of the flasks were also detached with a cell scraper and the suspension was centrifuged at $25^{\circ} \mathrm{C}$ at $300 \mathrm{xg}$ for 5 minutes. The cells were re-suspended in fresh culture medium, transferred to new tissue culture plates and used for subsequent sub-cultures. Viable cell density was estimated by counting of cells excluding trypan blue dye using a hemocytometer (Neubauer, Germany). The sub-culturing process was repeated several times.

Examination of Gene Expression of Proteins Involved in Biomineralization in in vitro Cultured Mantle Epithelial Cells

\section{Total RNA Extraction}

Mantle epithelium was collected from both the valves. The tissue pieces were sliced using a sterile scalpel taking utmost care to avoid RNase contamination. The sliced pieces were homogenized well in lysis solution mixed with 2 Mercaptoethanol to minimize RNA degradation. In vitro cultured mantle epithelial cells $\left(2.6 \times 10^{6}\right.$ cells $)$ were collected from culture plates at around 15 days of culture. The adherent cells were scraped from the culture plates and centrifuged at 1558 x g. The supernatant was discarded and the cell pellet was kept intact. Total RNA was extracted from both homogenized mantle tissue and in vitro cultured mantle epithelial cells using GenElute $^{\mathrm{TM}}$ Mammalian Total RNA Miniprep kit (SigmaAldrich, St. Louis, USA) as per manufacturer's instructions. The quality and quantity of RNA was determined using UV/Visible spectrophotometer (Thermo-Scientific Nanodrop 2000C).

\section{Reverse Transcriptase PCR Analysis}

Reverse transcription was performed using $1 \mu \mathrm{g}$ of total RNA from both mantle tissue and in vitro cultured mantle epithelial cells. The first strand cDNA was synthesized using First-Strand cDNA Synthesis Kit (GE Healthcare) as per manufacturer's instructions. The first strand cDNA was used as template to amplify nacrein and amorphous calcium carbonate binding protein (ACCBP) with the following primers (nacreinF5'-CACTTTGAACCTACACGC-3', nacreinR5'TATAAGCACATTCCAGGATCC-3'; ACCBPF5'GACATGGAACAAAGATGGTGGA-3', ACCBPR5'CTGTGGCTGGAATGGTTGG-3'). Actin gene was used as housekeeping positive control of cDNA and amplified using the primer ActinF 5'-CTCCTCACTGAAGCCCCCCTCA-3', ActinR 5'- ATGGCTGGAATAGGGATTCTGG-3'. The amplification of the genes was carried out in a final volume of 
$25 \mu 1$ in a Applied Biosystems 9902 Verti Thermal Cycler with the following cycling conditions, Nacrein: Initial denaturation at $95^{\circ} \mathrm{C}$ for 2 mins followed by 35 cycles of denaturation at $95^{\circ} \mathrm{C}$ for $45 \mathrm{~s}$, annealing temperature ranging from $46^{\circ} \mathrm{C}$ to $48^{\circ} \mathrm{C}$ for $50 \mathrm{~s}$, extension at $72^{\circ} \mathrm{C}$ for $25 \mathrm{~s}$ and final extension at $72^{\circ} \mathrm{C}$ for 4 mins., ACCBP: Initial denaturation at $95^{\circ} \mathrm{C}$ for 2 mins followed by 35 cycles of denaturation at $95^{\circ} \mathrm{C}$ for $45 \mathrm{~s}$, annealing temperature ranging from $54^{\circ} \mathrm{C}$ to $57^{\circ} \mathrm{C}$ for $50 \mathrm{~s}$, extension at $72^{\circ} \mathrm{C}$ for $25 \mathrm{~s}$ and final extension at $72^{\circ} \mathrm{C}$ for 4 mins. The amplified products were checked in 1.5 percent agarose gel prepared with $1 \mathrm{X}$ TBE buffer. The size of the amplified products were checked with $100 \mathrm{bp}$ DNA ladder loaded and run along with the samples in the same gel. The amplified products were sequenced using Applied Biosystems 3730/3730xl DNA Analyzer.

\section{In vitro Trials to Induce Nacre Formation on Bead Nuclei in Semi-Solid Substrate}

Agarose (Sigma-Aldrich, St. Louis, USA) was dissolved in the yeast supplemented SSW culture medium and dispensed into wells of multi-well culture plates and left undisturbed for a few minutes for the medium to solidify. Sterile nuclear beads $(2 \mathrm{~mm}$ dia; $n=12$ ) were placed in spherical depressions made in the centre of the semi-solid agar substrate in cell wells. A suspension of granulated epithelial cells in culture medium was transferred to the wells containing beads and the plates were left undisturbed to induce coating of nacre on the beads. Culture medium was replenished at periodic intervals for maintaining cell viability.

\section{Examination of Nacre Deposition on Bead Nuclei}

Examination of nacre deposits formed on the surface of the nuclear beads was carried out by scanning electron microscopy (SEM; FEI Quanta FEG 200, Thermo Fischer Scientific, USA), after 60 days of incubation. The elemental composition of the nacre deposited on the bead nucleus was determined by energy dispersive X-ray analysis (EDAX). Photographs of a cross section of the incubated beads were also taken by SEM, by making a cut on the surface of the bead nucleus using a surgical blade. The mineral form of the calcium carbonate (nacre) coating on bead surface was determined using Fourier Transform Infrared Spectrometry. All spectra were recorded in the wave number range of 400 to $4000 \mathrm{~cm}^{-1}$.

\section{RESULTS}

\section{Mantle Explant Cultures and Development of Primary Cultures}

Examination of the mantle explants around 24 hours after culture initiation showed proliferation of a large quantity of cells, with a mixture of epithelial cells, hyalinocytes and fibroblast-like cells (Figure 1). After a few days of culture, the epithelial cells developed pseudopodial projections which later developed into networks containing granulated cells. Granulated cells matured after several days in culture and displayed the presence of colored granules with a purple hue. The mature cells finally liberated these granules, which then induced nacre crystal formation on the bottom of the culture vessels.

Cultures of mixed cells released from the mantle explants were subjected to periodic sub-culturing by partially transferring cells in culture into new plates, replacing part of the old medium with fresh medium. Transferred cells successfully attached to the new surface. Repeated sub-culturing of the mantle cell cultures led to the formation of primary cultures comprising only granulated epithelial cells over a period of time (Figure 2), which could be successfully maintained in a viable condition. Viable cell density estimated by counting of cells excluding trypan blue dye was found to be $87 \%$.

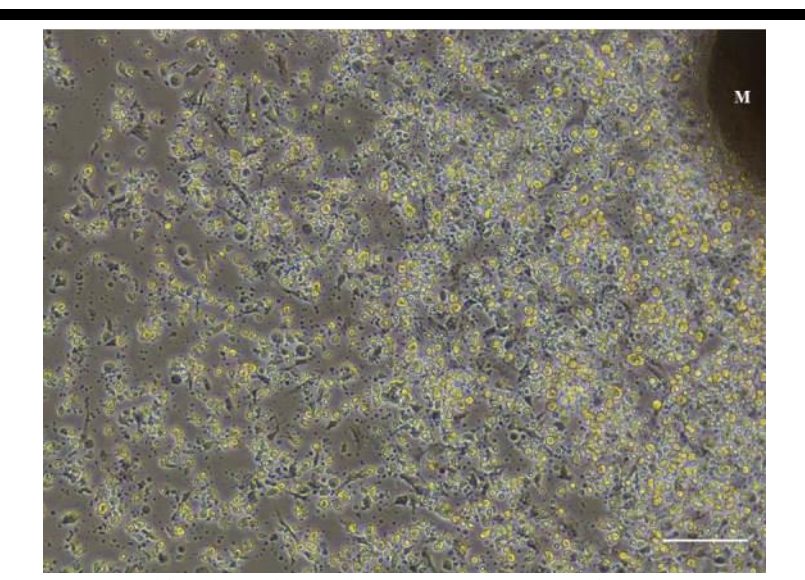

Figure 1. Proliferation of cells from mantle explant of the black-lip pearl oyster, Pinctada margaritifera cultured for 24 hours, observed in phase contrast mode. M- mantle; scale bar: $100 \mu \mathrm{m}$.

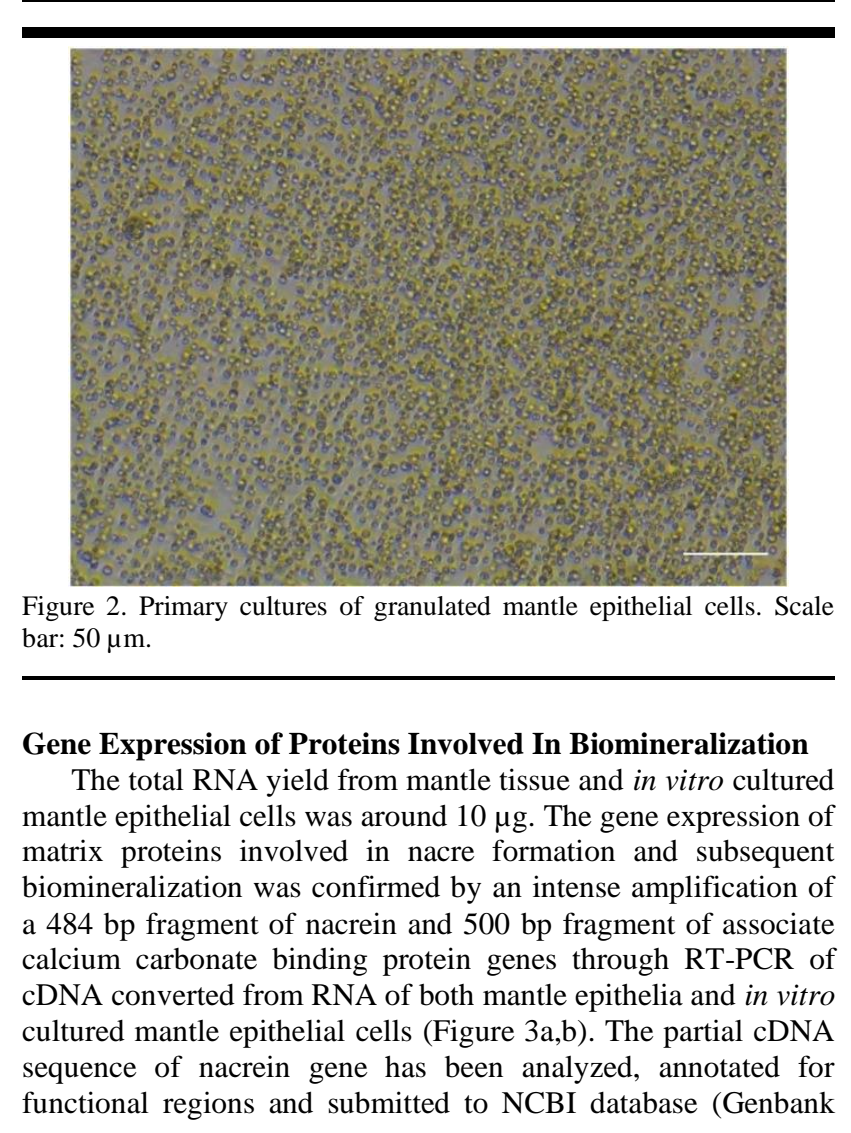




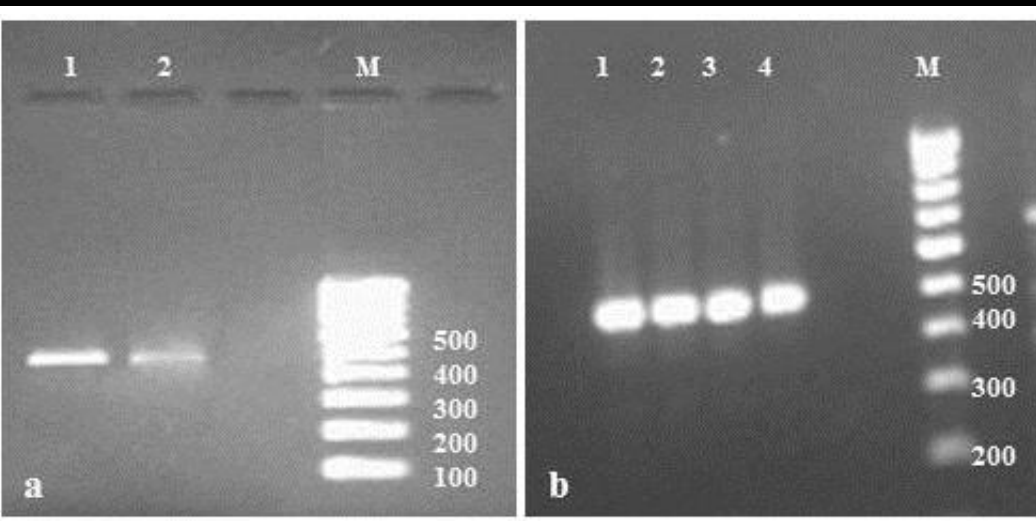

Figure 3. Gene expression of nacre associated proteins from mantle tissue and cultured mantle epithelial cells. a) Nacrein (484 bp) - lane 1: cells, lane 2: mantle tissue; b) ACCBP (500 bp) - lanes 1, 2: cells, lanes 3, 4: mantle tissue. M- 100 bp ladder.

accession number: MK531554). Expression of genes involved in biomineralization was as good in in vitro cultured cells as it was in native mantle tissue.

\section{Nacre Formation on Bead Nuclei in Semi-Solid Substrate}

Observation under a light microscope about 24 hours after incubation of bead nuclei with granulated mantle epithelial cells in an agar substrate showed aggregation of epithelial cells in the agar substrate surrounding the bead nucleus (Figure 4).

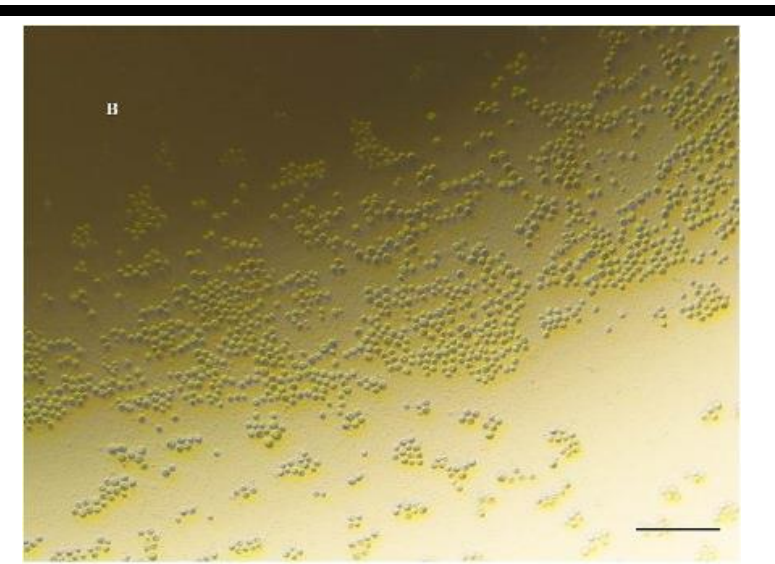

Figure 4. Aggregation of granulated mantle epithelial cells around nuclear bead in semi-solid substrate during nacre induction trial. B -bead nucleus; scale bar: $50 \mu \mathrm{m}$.

After about two weeks of incubation, a brown coloration was seen all over the bead on visual observation. Evaluation of nacreous layer formation on the surface of the nuclear beads by SEM after 60 days of incubation revealed a very good brick and mortar formation characteristic of nacre, comprising of $\mathrm{CaCO}_{3}$ platelets and matrix proteins (Figure 5a).The elemental composition of the deposits on the bead nucleus was determined by energy dispersive X-ray analysis (EDAX). Calcium, carbon and oxygen were found to be the prominent peaks in the spectra, with calcium content being $87.91 \%$ (Figure 5 b).Analysis by FTIR confirmed the coated material to be aragonite with a main spectrum band at $859 \mathrm{~cm}^{-1}$ (Figure $5 \mathrm{c}$ ).
After 60 days, $60 \%$ of the nacre coated beads also displayed a lustrous hue, signifying the production of a pearly nacreous material (Figure 6a; 6b). This was captured using a regular camera. Scanning electron micrographs of a cross section of the incubated beads were also taken by making a shallow cut on the surface of the bead nucleus using a surgical blade. The crosssection revealed a pattern of arrangement of aragonite tablets similar to that seen in cross sections of the nacre layer of shell of molluscs (Figure 7).

\section{DISCUSSION}

Cultures with a mixture of epithelial cells, hyalinocytes, hemocytes and other cell types as previously reported for $P$. fucata (Dharmaraj and Suja, 2002, 2004, 2006; Suja and Lakshmana Senthil, 2019), abalone mantle cells (AuzouxBordenave et al. 2007; O'Neill et al., 2013; Suja 2003; Suja and Dharmaraj, 2005) and P. margaritifera (Jayasankar et al., 2018) were obtained from mantle explants. Morphology and cellular behaviour similar to that described in the previous cell cultures were confirmed during this study.

Cell culture medium is the most critical component for culture initiation, cell proliferation and viability. Several kinds of culture media including L-15, DMEM/F12 and TCM-199 popular for animal cell culture, have been modified for use in molluscan cell culture, with varying degrees of success (Nagai et al., 1998; Rinkevich, 2005; Yoshino et al., 2013). Suja and Dharmaraj (2005) cultured Haliotis varia mantle cells for 370 days in M199 medium with supplements. The characteristics of H. varia mantle cells in F12, MI99 and L-15 serum free media were reported by Suja et al. (2007).

However, in this study a relatively simple and cost effective culture medium composed of sterilized seawater supplemented with $0.1 \%$ yeast, developed by Jayasankar et al. (2018) was used successfully for culture of $P$. margaritifera mantle explants. Sea water, with or without added factors has been used in earlier studies too as a culture medium for invertebrate cells (Cecil, 1969; Qiao et al., 2003; Suja et al., 2017; Suja and Dharmaraj, 2019; van der Merwe et al. 2010). The close resemblance of these media to natural seawater, the habitat of marine molluscs, in terms of $\mathrm{pH}$ and osmolarity is what makes it an attractive 

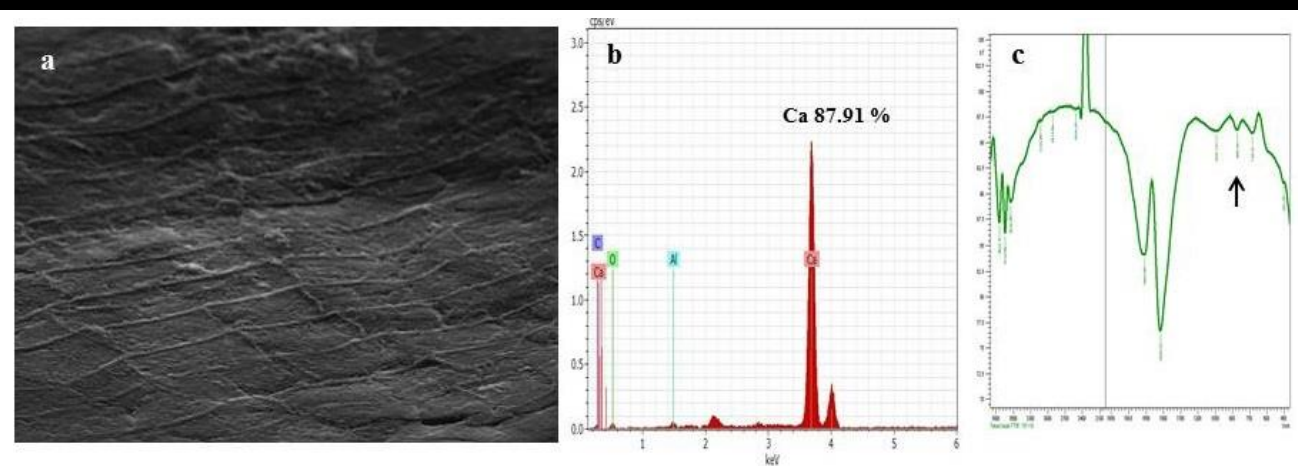

Figure 5. Evaluation of bead surface after nacre coating trial. a) Scanning electron microscope image of coated bead surface showing "brick" and "mortar" formation characteristic of nacre; b) X-ray spectra of coated bead analyzed by energy dispersive X-ray analysis (EDAX); c) FTIR spectra of the material collected from the nacre-coated bead surface; arrow indicates spectrum of aragonite at $859 \mathrm{~cm}^{-1}$.

alterative to complex cell culture media. Primary cultures of granulated mantle epithelial cells were established and maintained in a viable condition for several months in this medium, and used for nacre induction trials.

In order to assess whether mantle epithelial cells in culture retain their functional characteristics of biomineralization, gene expression of two matrix proteins, nacrein and amorphous calcium carbonate binding proteins (ACCBP), which play an important role in formation of the nacreous layer was examined in both cultured cells and in native mantle tissue. Nacrein has been reported to be involved in amorphous calcium carbonate and nacreous layer formation by providing $\mathrm{HCO}_{3}$, while ACCBP has been shown to be very important for the formation of the first nacreous layer (Liu et al., 2012).

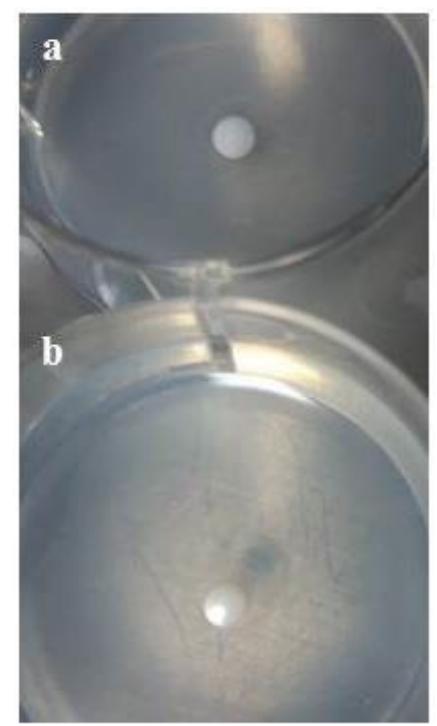

Figure 6. Lustre formation on in-vitro nacre coated beads observed by camera; a) uncoated control bead; b) experimental bead showing lustre.

Results of gene expression studies of the mantle cell cultures were in agreement with that in the mantle tissue, which demonstrated that in vitro cultured mantle epithelial cells could synthesize shell matrix proteins similar to the mantle epithelia in vivo. The amplification results of nacrein are in accordance with previous reports in P. fucata by Gong et al. (2008) and in $P$. margaritifera by Jayasankar et al. (2018). Gong et al. (2008) reported the expression of nacrein in mantle cell cultures of $P$. fucata. Xiang et al. (2014) demonstrated that expression of $\mathrm{ACCBP}$ and nacrein genes was retained in the in vitro cultured mantle cells of $P$. fucata over a period of time after culture initiation. In their study, Xiang et al. (2014) also detected ACCBP and nacrein proteins in the mantle culture medium, showing that matrix proteins were synthesized intracellularly and secreted by the mantle cells. Therefore, primary mantle cell cultures retain the functional characteristics of nacre secretion and are suitable for in vitro pearl culture studies.

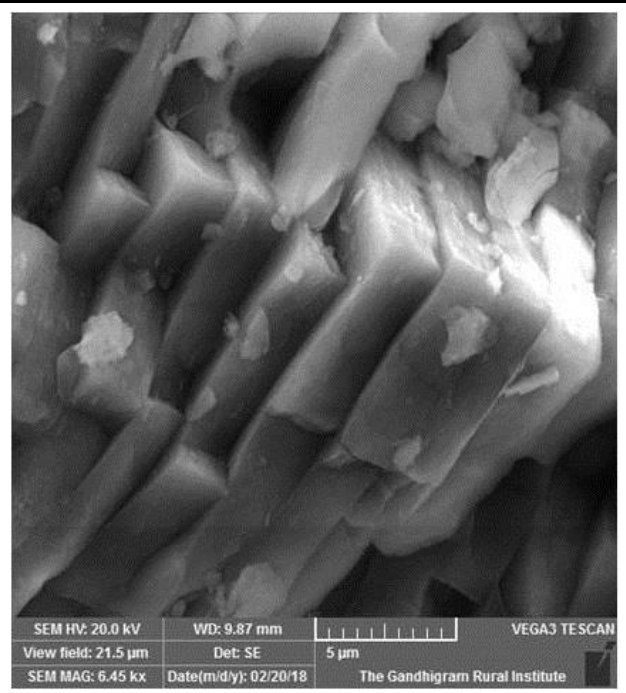

Figure 7. Scanning electron microscope image of cross-section of nacre coated bead.

Incubation of bead nuclei in a semi-solid agar substrate with culture medium containing a suspension of granulated epithelial cells was able to induce a thick nacreous layer formation over the beads. Many of the earlier reports have been on nacre 
formation under in vivo conditions. In an experiment conducted by Machii (2007), when cell suspensions containing cultured epithelial cells and granular and agranular hemocytes from $P$. fucata were injected into a host oyster implanted with an inorganic bead, nacreous layer formation could be induced on the bead. Awaji et al. (2014) transplanted a nucleus carrying a small pit inoculated with mantle outer epithelial cells from P. fucata into a recipient oyster which resulted in pearl formation. Jayasankar et al. (2018) have demonstrated nacre formation on nuclear beads in vitro when they were incubated in culture medium containing mature granulated mantle epithelial cells from $P$. margaritifera, without any substrate. The formation of pearl sac and nacreous layer over nuclear beads incubated with mantle explants of the abalone, $H$. varia, pearl oysters $P$. fucata and Pteria avicular in culture vessels, using agar as substrate and M199 as the culture medium has been reported by Dharmaraj and Suja, 2004, 2006, 2010; Suja 2003; Suja and Dharmaraj 2019; Suja and Lakshmana Senthil, 2019. Cells were shown to proliferate from the explants and spread around and over the bead, forming a pearl sac of epithelial cells.

Scanning electron microscopic (SEM) examination of the nuclear bead surface after incubation for 60 days showed the presence of a distinct brick and mortar formation which is characteristic of nacre, with aragonite platelets resembling the bricks and matrix proteins forming the mortar. This pattern was similar to that observed by Jayasankar et al. (2018) after 60 days of bead incubation with in vitro cultured mantle cells of $P$. margaritifera without any substrate. However, analysis of the elemental composition of the nacreous layer on the bead by energy dispersive X-ray analysis (EDAX) in the present study revealed a much higher content of calcium $(87.91 \%)$ than that observed by Jayasankar et al. (2018), which was $48.48 \%$.The increased calcium content of the nacre coating could be attributed to the semi-solid substrate used in this study. A semisolid medium has been shown to provide a better substratum for holding the bead to keep it stationery and facilitate nacre deposition over it (Suja, 2003, 2004, 2006, 2010, Suja and Lakshmana Senthil, 2019). In their trials on in vitro nacre induction on beads with mantle explants from pearl oyster and abalone using an agar substrate, Suja and Lakshmana Senthil (2019) also observed higher contents of calcium $(56.27 \%$ in $P$. fucata and $51.08 \%$ in $H$. varia) than that found on cultured pearls $(41 \%)$, similar to the results obtained in this study. Analysis by FTIR showed a main spectrum band at $859 \mathrm{~cm}^{-1}$, similar to that observed by Bellaaj-Zouari et al. (2011) for the nacreous layer of $P$. radiata shell, confirming the aragonitic nature of the coated material.

After 60 days, the nacre coating on $60 \%$ ofexperimental beads exhibited iridescent color, similar to the lustre seen in pearls. Snow et al. (2004) established that the primary color and lustre of pearls arise from the interference of light within the binding regions of the aragonite tiles. Suja (2019) reported the formation of lustrous pearl through the mantle tissue culture of abalone. Previous reports have also shown that during the early stages of pearl formation within the pearl sac, a calcitic prismatic layer is first formed on the nucleus, followed by an aragonitic nacreous layer formed on the prismatic layer (Wada, 1962; Hongyan et al., 2007; Inoue et al., 2011), which imparts lustre to the pearl. Wada (1999) reported that the quality of lustre on nacreous pearls is determined by the ratio of the thickness of the lower prismatic layer to that of the upper nacreous layer, with a lower ratio of the prismatic layer to the nacreous layer leading to the formation of high quality lustrous pearls.

Scanning electron micrography of a cross section of the incubated beads at 60 days revealed a pattern of arrangement of aragonite tablets similar to that seen in cross sections of the nacre layer of shell of molluscs (Rousseau, 2011).

\section{CONCLUSIONS}

The study confirmed that mantle cells cultured in the simple culture medium developed was able to retain the functional characteristics of nacre secretion, and is therefore suitable for development of in vitro pearl culture technology in oysters. Use of a semi-solid substrate for holding the bead nucleus immobile helps improve nacre deposition for development of in vitro pearls. The expression of nacrein and ACCBP genes in both mantle tissue and in vitro cultured mantle epithelial cells support the regulatory molecular mechanism of these genes in biomineralization and pearl formation.

\section{ACKNOWLEDGMENTS}

The authors wish to thank the Director, the Head of Marine Biotechnology Division and the Scientist-in-Charge, Chennai, of the ICAR-Central Marine Fisheries Research Institute for facilitating the work. The authors are also grateful to the Director, ICAR-Central Institute of Brackishwater Aquaculture for his support and for facilities extended. The laboratory assistance of T. Balaraman is acknowledged. This research received institutional grant from ICAR-CMFRI.

\section{LITERATURE CITED}

Auzoux-Bordenave, S.; Fouchereau-Peron, M.; Helleouet, M.N., and Doumenc, D., 2007. CGRP regulates the activity of mantle cells and hemocytes in abalone primary cell cultures. Journal of Shellfish Research, 26, 887-894.

Awaji, M. and Machii, A., 2011. Fundamental studies on in vivo and in vitro pearl formation: contribution of outer epithelial cells of pearl oyster mantle and pearl sacs. Aqua- BioScience Monographs, 4, 1-39.

Awaji, M.; Yamamoto, T.; Kakinuma, M.; Nagai, K., and Watabe, S., 2014. Pearl formation by transplantation of outer epithelial cells isolated from the mantle of pearl oyster Pinctada fucata. Nippon Suisan Gakkaishi, 80, 578-588 (Japanese).

Bellaaj-Zouari, A.; Dkhili, S.; Gharsalli, R.; Derbali, A., and Aloui-Bejaoui, N., 2011. Shell morphology and relative growth variability of the invasive pearl oyster Pinctada radiata in coastal Tunisia. Journal of the Marine Biological Association of the United Kingdom, 92 (3), 553-563.

Cecil, J.T., 1969. Mitosis in cell cultures from cardiac tissue of the surf clam Spisula solidissima. Journal of Invertebrate Pathology, 14, 407-410.

Dharmaraj, S. and Suja, C.P., 1998. Tissue culture in pearl oyster. In: Proceedings of the first National Seminar on Trends in Marine Biotechnology. Institute for Coastal Area Studies (Nagercoil, India), pp. 75-79. 
Dharmaraj, S. and Suja, C.P., 2001. Biotechnological approach in in-vitro pearl production. In: Menon, N.G. and Pillai, P.P. (eds.), Perspectives in Mariculture. The Marine Biological Association of India, pp. 405-412.

Dharmaraj, S. and Suja, C.P., 2002. Development of technology in in vitro pearl production in India. Bulletin of the Malacological Society of London, 39, pp. 9 and 11.

Dharmaraj, S. and Suja, C.P., 2004. Pearl production techniques through tissue culture in the Indian pearl oyster (Pinctada fucata) and in the abalone (Haliotis varia) and other pearl producing molluscs. Indian patent No.,1987/DEL/04 (IPR-Indian Council of Agricultural Research).

Dharmaraj, S. and Suja, C.P., 2006. Pearl production techniques through tissue culture in the Indian pearl oyster (Pinctada fucata) and in the abalone (Haliotis varia) and other pearl producing molluscs. International Patent No., PCT/IB 2006/003299.

Dharmaraj, S. and Suja, C.P., 2010. In vitro pearl production using marine organisms. US Patent 2010/0055787 A1.

Gong, N.; Ma, Z.; Li, Q.; Li. Q.; Yan, Z.; Xie, L., and Zhang. R., 2008. Characterization of calcium deposition and shell matrix protein secretion in primary mantle tissue culture from the marine pearl oyster Pinctada fucata. Marine Biotechnology, 10, 457-465.

Hedegaard, C., 1997. Shell structures of the recent Vetigastropoda. Journal of Molluscan Studies, 63, 369377.

Hongyan, M.; Belli, Z.; Lee, I.S.; Zuolu, Q.; Zhangfa, T., and Shuheng, Q., 2007. Aragonite observed in the prismatic layer of seawater-cultured pearls. Frontiers of Materials Science in China, 1 (3), 326-329.

Inoue, N.; Ishibashi, R.; Ishikawa, T.; Atsumi, T.; Aoki, H., and Komaru, A., 2011. Gene expression patterns in the outer mantle epithelial cells associated with pearl sac formation. Marine Biotechnology, 13, 474-483.

Jayasankar, V.; Srinivasa Raghavan, V.; Suja, C.P., and Divipala, I., 2018. Nacre formation by epithelial cell cultures from mantle of the black-lip pearl oyster, Pinctada margaritifera. In vitro Cellular \& Development Biology - Animal, 54 (7), 477-485.

Liu, X.; Li, J., and Xiang, L., 2012. The role of matrix proteins in the control of nacreous layer deposition during pearl formation. Proceedings of Royal Society of Biological Sciences, 279, 1000-1007.

Liu, Y.; Shigley, J.E., and Hurwit, K.N., 1999. Iridescence color of a shell of the mollusk Pinctada margaritifera caused by diffraction. Optics Express, 4, 177-182.

Machii, A., 2007. Pearl. Applied Cell Biology, 24, 1-13 (in Japanese with English abstract).

Nagai, T.; Nakatsugawa, T; Nishizawa, and Muroga, K., 1998. Primary culture of hemocytes from Japanese black abalone Nordotis discus discus. Fish Pathology, 33 (3), 147-148.

O’Neill, M.; Gaume, B.; Denis, F., and Auzoux-Bordenave, S., 2013. Expression of biomineralisation genes in tissues and cultured cells of the abalone Haliotis tuberculata. Cytotechnology, 65, 681-681.

Qiao, D.; Nikitina, L.A.; Buznikov, G.A.; Lauder, J.M.;
Seidler, F.J., and Slotkin, T.A., 2003. The sea urchin embryo as a model for mammalian developmental neurotoxicity: ontogenesis of the high affinity choline transporter and its role in cholinergic trophic activity. Environmental Health Perspectives, 111, 1730-1736.

Rinkevich, B., 2005. Marine invertebrate cell cultures: new millennium trends. Marine Biotechnology, 7, 429-439.

Rousseau, M., 2011. Nacre, a Natural Biomaterial. In: Rosario Pignatello (ed.), Biomaterials Applications for Nanomedicine, pp. 281-298.

Snow, M.; Pring, A.; Self, P.; Losic, D., and Shapter, J., 2004. The origin of the colour of pearls in iridescence from nano-composite structures of the nacre. American Mineralogist, 89 (10), 1353-1358.

Suja, C.P., 2003. Mantle tissue culture of abalone, Haliotis varia Linnaeus: Manonmanium Sundaranar University, Ph.D. Dissertation.

Suja, C.P., 2009. Pearls from Abalone through tissue culture A new approach in Biotechnology (in Hindi). Matsygandha. CMFRI Special Publication No. 102, pp. 28-33.

Suja, C.P., 2019. In vitro Pearl Culture Techniques: A Biotechnological Approach. CMFRI Special Publication No. 131, pp. 60.

Suja, C.P. and Dharmaraj, S., 2005. In vitro culture of mantle tissue of the abalone Haliotis varia Linnaeus. Tissue and Cell, 37, 1-10.

Suja, C.P. and Dharmaraj, S., 2019. Cell characteristics in explant cultures. In: Suja, C.P. (ed.), In vitro Pearl Culture Techniques: A Biotechnological Approach. CMFRI Special Publication No. 131. pp. 12-16.

Suja, C.P. and Dharmaraj, S., 2019. Experiments with the mantle tissue of different pearl producing molluscs. In: Suja, C.P. (ed.), In vitro Pearl Culture Techniques: A Biotechnological Approach. CMFRI Special Publication No. 131. pp. 17-33.

Suja, C.P. and Lakshmana, S., 2019. Organ culture of mantle tissue of different pearl producing molluscs. In: Suja, C.P. (ed.), In vitro Pearl Culture Techniques: A Biotechnological Approach. CMFRI Special Publication No. 131. pp. 34-53.

Suja, C.P.; Srinivasa Raghavan, V.; Jayasankar, V.; Divipala, I.; Mohamed, B.M.; Mary K.B., and Vijayan, K.K., 2017. Evaluation of different media for cell proliferation in mantle tissue culture of the green mussel, Perna viridis (Linnaeus, 1758). Indian Journal of Fisheries, 64 (Special Issue), 224-228.

Suja, C.P.; Sukumaran, N., and Dharmaraj, S., 2007. Effect of culture media and tissue extracts in the mantle explant culture of abalone, Haliotis varia Linnaeus. Aquaculture, 271 (1-4), 516-522.

van der Merwe, M.; Auzoux-Bordenave, S.; Niesler, C., and Roodt-Wilding, R., 2010. Investigating the establishment of primary cell culture from different abalone (Haliotis midae) tissues. Cytotechnology, 62, 265-277.

Wada, K., 1962. Biomineralogical studies on the mechanism of pearl formation. Bulletin of Natural Pearl Research Laboratory, 8, 948-1059 (in Japanese with English abstract). 
Wada, K., 1999. Science of the Pearl Oyster. Shinju Shinbunsha, Tokyo. pp. 336 (in Japanese).

Weiss, I.M.; Kaufmann, S.; Mann, K., and Fritz, M., 2000. Purification and characterization of perlucin and perlustrin, two new proteins from the shell of the mollusc Haliotis laevigata. Biochemical and Biophysical Research Communications, 267, 17-21.

Xiang, L.; Kong, W.; Su, J.; Liang, J.; Zhang, G.; Xie, L., and Zhang, R., 2014. Amorphous calcium carbonate precipitation by cellular biomineralization in mantle cell cultures of Pinctada fucata. PLoS ONE, 9 (11), e113150. Xiang, L.; , Su, J.; Zheng, G.; Liang, J.; Zhang, G.; Wang, H.; Xie, L., and Zhang, R., 2013. Patterns of expression in the matrix proteins responsible for nucleation and growth of aragonite crystals in flat pearls of Pinctada fucata. PLoS ONE, 8 (6), e66564.

Yoshino, T.P.; Bickham, U., and Bayne, C.J., 2013. Molluscan cells in culture: primary cell cultures and cell lines. Canadian Journal of Zoology, 91 (6), 391-404. 